\title{
Introduction
}

\section{Boundary Crossing}

\section{The Editors}

The preparation of European Comic Art 8(1) has been overshadowed by the shocking and tragic murder of Charlie Hebdo cartoonists Cabu, Charb, Honoré, Tignous and Wolinski on 7 January 2015. As a way of memorialising these artists, we have invited Jane Weston Vauclair to contribute an article to this issue, assessing the significance of the magazine in the history and current state of French social and political satire. Indeed, beyond doubt is the iconic status of Charlie Hebdo as representing a distinctively French, but known to an international readership, tradition of disrespect for the sacred and the hypocritical, and for beaufitude in all its forms. ${ }^{1}$ However, the very untranslatability of that term, invented by Cabu, suggests that comic art, and perhaps satire in particular, may not always travel easily across borders. Mark McKinney has argued in his blog post on the Berghahn Books website ${ }^{2}$ that the meanings of the Charlie cartoons are far from transparent and universally readable, but have to be understood within a particular cultural and political context and reference system. ${ }^{3}$

That context is, of course, itself a complex and diverse one. It involves tensions and power relations between the centre and the margins. It is, moreover, one within which the symbolism of nation remains potent, as we saw in the demonstrations that followed the massacre, but where national identity is multiple and hybrid, where borders are both real

1 See the series Les Beaufs created by Cabu in Charlie Hebdo in 1973. The beauf (short for beau-frère [brother-in-law]) is small-minded, reactionary and misogynist.

2 Mark McKinney, 'The Meanings of Charlie Hebdo and the Value of Scholarship on Comics and Cartoons', Berghahn Journals blog, http://berghahnbooks.com/blog/ charlie-hebdo-european-comic-art (posted 16 January 2015).

3 Such a view does not, of course, preclude debate about the content of Charlie Hebdo: it would hardly be appropriate for such debate to be stifled, and indeed it still goes on within the ECA editorial board. 
and permeable, and where the global coexists with a strongly rooted sense of the local. Articles in this edition of ECA further pursue the theme of boundary crossing by examining negotiations between the national and the transnational from several different angles, including subject matter, influences, and critical traditions.

Karrie Fransman's award-winning comic Over Under Sideways Down recounts the story of the teenaged Ebrahim, forced to leave Iran to escape arrest on political grounds, who endured cruelty at the hands of human traffickers on his journey and arduous and interminable interrogation on his arrival in the UK. Fransman's page layout and use of visual metaphor capture the young man's sense of dislocation and loss of stable identity, aching nostalgia for a homeland and tentative settlement in London, a place of safety if not yet a home. In her highly thoughtful responses to interview questions, Fransman explains how she brought the resources of the medium into play to explore national identity and its loss.

Where Fransman tells the story of an individual, albeit one whose experience is representative of that of many others, Jennifer Howell's article considers the portrayal by Clément Baloup, the French cartoonist of Vietnamese heritage, of the collective experience of diaspora in France and the United States. As Howell argues, Baloup's work asserts a Viet Kieu identity born out of exile and loss, not only distinct from the national identities of the country of origin and the host countries, but also constantly evolving. Whereas, she maintains, the representation of 'Vietnam' in the mainstream media has been defined and limited by certain iconic and oft-circulated photographs and film clips, Baloup uses Vietnamese foodways as a cultural signifier that challenges any such fixity. The recurrence in his work of meals, meal preparation and the passing on of recipes functions, Howell suggests, both to evoke and visualise memories of a painful past and to depict shared membership of a contemporary Viet Kieu transnational community.

Clément Baloup has published over a dozen comic books that he drew and/or scripted, as well as numerous other comics in group publications. Following Howell's analysis of his work, in his own article, he connects his trajectory as a cartoonist to the wide array of comics that influenced him, ranging from experimental works by Amok, L'Association and Fréon, to Art Spiegelman's Holocaust biography Maus, Baru's contemporary, multicultural road-trip fiction L'Autoroute du soleil [The highway of the sun] and the science fiction series Akira by Katsuhiro Otomo, who won the grand prize at the Angoulême comics festival 
(FIBD) in January 2015. After graduating from the École européenne supérieure de l'image [European Graduate School of the Image] in Angoulême, Baloup joined Zarmatelier, a group of cartoonists who share a studio in Marseille. He devotes much of his article to explaining his creative artistic process in his comics with Vietnamese themes. These include biographical narratives about Vietnamese exiles and emigrants in France and the United States, autobiographical stories about time spent in Vietnam, and historical fictions set in France and Vietnam during the French colonial occupation of that country.

Zeina Abirached has published several semiautobiographical comics about her childhood experiences and environment in Beirut during the Lebanese Civil War. Here she outlines her artistic itinerary, which includes her formal education in fine arts, cartooning and animation, as well as a wide variety of other artistic, literary and cultural influences. The forgetting or setting aside of past (wartime) experiences in presentday Lebanon constitutes a major impetus for her artistic retrieval, reconstruction and commemoration of that past in her comics. She describes the centrality of geography and space in her youth, and their relation to her comics: the walling off of physical and mental spaces during the war, their reopening with the return of peace, and the creative ways that she has incorporated those dimensions into her comic books, starting with [Beyrouth] Catharsis. The formal experiments of OuLiPo, the French literary group, were especially important to Abirached as she reworked the comic strip page and its narrative and spatial ordering in her foldout comic, 38, rue Youssef Semaani 38 Youssef Semaani Street]. It offers readers multiple choices in their exploration of the stories of characters in an apartment building modelled on the one where her family lived. The artist describes the genesis of Le Jeu des hirondelles [A Game for Swallows], which she began after stumbling upon a television news report set in Beirut during the civil war and featuring an interview in which her own grandmother claimed to be safe in her apartment, despite the obvious omnipresence of wartime danger. In that book, Abirached explores both spatial and temporal distortions imposed by war, as well as the social structure of the Lebanese community living in her building. Abirached also uses this community to provide insight onto the prewar past, what she calls 'Lebanon's golden years'. Moreover, she reflects on cultural adjustments called for by migratory movements to escape the war, both within Lebanon and abroad. Abirached then describes the mnemonic, artistic structure of her most recent book, Je me souviens: Beyrouth [I Remember Beirut], 
which was inspired by Je me souviens, a collection of fragmentary reminiscences published by Georges Perec, a member of OuLiPo (Perec's book was itself inspired by Joe Brainard's I Remember).

Our next article concerns artistic questioning and renewal as subject to transnational influences. Barbara Uhlig discusses the work of the Italian artist Lorenzo Mattotti and the French artist Nicolas de Crécy, both in the forefront of the transformation of European comics since the 1980s, in relation to earlier movements in fine art. Uhlig argues that from their beginnings in the early twentieth century, the visual style of Italian comics drew on suprematism and art nouveau, until standardisation based on the conventions established by American comics set in by midcentury. In the 1980s, however, a number of Italian comics artists revived styles associated with a historical avant-garde, such as futurism, expressionism and art deco, in a move to institute new forms of expression akin to the 'new seeing' of modernism. Uhlig then offers a detailed reading of Mattotti's Murmur and demonstrates its strong affinities with expressionism. She goes on to analyse Crécy's Fogliatto in terms of its alignment with a different strand of modernism, the Neuer Sachlichkeit [new objectivity] typified by the work of George Grosz and Otto Dix. Uhlig's reading draws out very specific borrowings from Dix in particular in relation to the grotesque subject matter and visual style. Through their reversion to modernism, Uhlig argues, Mattotti and Crécy have restored authenticity to an art form whose representative and narrative conventions were no longer capable of 'seeing'.

Finally, we are delighted that Renaud Chavanne has written for ECA our final article in which he offers a concise summation of his major book, La Composition de la bande dessinée [The composition of comics]. Chavanne's work both builds on and critiques that of earlier French theorists of page layout, most notably Benoît Peeters and Thierry Groensteen - both erstwhile contributors to ECA - and is innovative both in its focus on the strip as a key level of analysis and in its formulation of semiregularity and fragmentation as principles underlying the formal choices of comics artists, although he is at pains to insist on the inductive procedure that guides his work: the principles emerge from the study of existing comics, and are not assumed to be universal or immutable. Chavanne's classificatory system is elaborated from, and exemplified by, the work of artists from many comics cultures, including European, American and Japanese. Importantly, he also makes a move to initiate a dialogue between French and American theorists. Chavanne's article ends with a critical appraisal of Neil 
Cohn's approach to page layout. We hope that this transnational debate will continue.

Indeed, we know it will, not least at the joint International Bande Dessinée Society (IBDS) and graphic novel conference at the University of London Institute in Paris, from Monday 22 to Saturday 27 June 2015. The conference will take place in partnership with L'image Railleuse conference on caricature at the Institut national d'histoire de l'art. As the IBDS conference theme is Voyages, the boundary-crossing debates of this issue of ECA are set to continue. 